\title{
European Food and Drink Wholesalers and Sustainability
}

\author{
Peter Jones ${ }^{1 *}$, Daphne Comfort ${ }^{1}$, David Hillier ${ }^{2}$ \\ ${ }^{1}$ University of Gloucestershire, UNITED KINGDOM \\ ${ }^{2}$ University of South $W$ ales, UNITED KINGDOM \\ *Corresponding Author: pjones@glos.ac.uk
}

Citation: Jones, P., Comfort, D. and Hillier, D. (2017) European Food and Drink Wholesalers and Sustainability, European Journal of Sustainable Development Research, 1:1 (2017), 3.

doi: http://dx.doi.org/10.20897/ejosdr.201703

Received: May 3, 2016; Accepted: July 14, 2016; Published: January 17, 2017

\begin{abstract}
Purpose- The aim of this paper is to review and reflect on the sustainability agendas and achievements reported by Europe's leading food and drinks wholesalers.

Design/Methodology/Approach- The paper begins with a short introduction to corporate sustainability, sustainability reporting and food and drinks wholesaling within Europe and the empirical material for the paper is drawn from reports and information posted on the leading food and drinks wholesalers' corporate websites.

Findings- There are marked variations in the extent to which Europe's leading food and drinks wholesalers reported and provided information on their sustainability agendas and achievements. These agendas and achievements embraced a wide range of environmental, social and economic issues but the reporting process had a number of weaknesses that undermine its transparency and credibility. The authors also argue that the leading food and drinks wholesalers' definitions of, and commitments to, sustainability are principally driven by business imperatives as by any fundamental concern to maintain the viability and integrity of natural and social capital. More critically the authors argue that this approach is couched within existing business models centred on continuing growth and consumption

Limitations- The paper is a preliminary review of the sustainability agendas and achievements publicly reported by Europe's leading food and drinks wholesalers.

Originality- The role of Europe's wholesale sector in addressing sustainability has received scant attention in the academic literature and this paper will interest academics and students in business management and marketing and employees and executives working in the distribution sector of the economy.
\end{abstract}

Keywords: corporate sustainability, European food and drinks wholesalers, economic growth, sustainable consumption

\section{INTRODUCTION}

Retailers, and more particularly a small number of large superstore and supermarket operators, are the major players in the distribution of food and drinks within Europe (Reynolds and Cuthbertson 2014). As such these large retailers are in a singularly powerful position to actively promote sustainability through their partnerships with their suppliers and through their daily interactions with millions of consumers. Over a decade ago Durieu (2003,) for example, argued that large retailers 'can greatly influence changes in production processes and consumption patterns and are well positioned to exert pressure on producers in favour of more sustainable choices.' In 2009 the European Commission and a number of leading European retailers launched a 'Retail Forum' as part of an initiative to promote more sustainable consumption. During the past decade all the leading food retailers have increasingly publicly recognised the impact 
of their operations on the environment, on society and on the economy, and they have pursued and publicised policies and programmes designed to manage these impacts as part of their developing corporate sustainability strategies. These policies and programmes and the achievements associated with them, which are usually captured and published annually in sustainability reports, have attracted increasing attention from researchers in business and management (e.g. Jones et. al. 2012).

While the large retailers are the dominant players in Europe's food distribution system wholesalers have ' $a$ pivotal role as the interface between producers, importers, manufacturers, retail and service providers' (Euro Commerce 2014) and arguably they also have an important role to play in promoting sustainability. However, the role of European wholesalers in addressing sustainability has received scant attention in the academic literature. With this in mind the aim of this paper is to provide an exploratory review of the sustainability commitments and achievements publicly reported by the leading players in the European wholesale industry. The paper begins with brief reviews of the growing interest in, and commitment to, corporate sustainability, sustainability reporting and of food and drink wholesaling within Europe by way of setting the context for the main body of the paper. This is followed by an exploratory review of the most recent sustainability reports and information published by some of the leading European wholesalers and by some reflections on current approaches to sustainability within the European wholesale industry. The paper draws its empirical information from the most recent sustainability reports and information posted on the selected European wholesalers' corporate websites.

\section{CORPORATE SUSTAINABILITY}

The concept of sustainability can be traced back as far as the thirteenth century but in more recent times it reemerged in the environmental literature in the 1970's (Kamara et. al. 2006) and since then it has attracted increasingly widespread attention. Diesendorf (2000) has argued that 'sustainability' can be seen as 'the goal or endpoint of a process called sustainable development.' The most widely used definition of sustainable development is 'development that meets the needs of the present without compromising the ability of future generations to meet their own needs' (World Commission on Environment and Development 1987) which Diesendorf (2000) suggests 'emphasises the long term aspect of the concept of sustainability and introduces the ethical principle of achieving equity between present and future generations.'

That said sustainability is a contested concept and as Aras and Crowther (2008) have argued sustainability is a controversial topic because it means different things to different people. There is a family of definitions essentially based in and around ecological principles and there are definitions which include social and economic development as well as environmental goals and which looks to embrace equity in meeting human needs. At the same time a distinction is often made between 'weak' and 'strong' sustainability with the former being used to describe sustainability initiatives and programmes developed within the existing prevailing economic and social system while the latter is associated with much more radical changes for both economy and society. Roper (2012) for example, suggested that 'weak sustainability prioritizes economic development, while strong sustainability subordinates economies to the natural environment and society, acknowledging ecological limits to growth.'

In simple terms corporate sustainability is seen to offer an alternative to the traditional business model based on growth and profit maximisation in that it also emphasises environmental protection, social justice and equity and sustainable economic development. However, there is currently little detailed consensus in defining corporate sustainability and a number of meanings can be identified. Polentz (2011), for example, claims 'ask ten different experts to define corporate sustainability you are likely to receive ten different answers' and suggests that 'part of the problem in defining such an amorphous term arises from its continuing evolution along with the ever-increasing entry of new stakeholders, an inconsistent set of state and federal laws and the constant onslaught of newly adopted federal and state laws.'

On the one hand there are definitions which seem to emphasise business continuity. Dyllick and Hockerts (2002), for example, define corporate sustainability as 'meeting the needs of a firm's direct and indirect shareholders (such as shareholders, employees, clients, pressure groups, communities etc.), without compromising its ability to meet the needs of future stakeholders as well.' Azapagic (2003) argued that corporate sustainability is an 'an invaluable tool for exploring ways to reduce costs, manage risks, create new products, and drive fundamental internal changes in culture and structure.' On the other hand, there are definitions that more explicitly embrace environmental and social goals and look to integrate these into a company's mission and core business strategy. Here corporate sustainability is concerned with 'companies contributing effectively to a global partnership for sustainable development. It is about companies delivering wide societal value including support for bealth and buman rights improvements, regional development and fair globalisation and respecting the environment by promoting technologies to reduce the emission of greenhouse gases and by implementing effective environmental risk management' (CSR Quest 2014). In a similar vein corporate sustainability has been defined as the discipline by which companies align decisionmaking about the allocation of capital, product development, brand and sourcing with the principles of sustainable development, in a resource-constrained world (Global Association of Corporate Sustainability Officers (2011). 


\section{SUSTAINABILITY REPORTING}

The growing interest in and commitment to sustainability has seen the emergence of sustainability reporting across a wide range of companies and organisations. During the last three decades the number of organisations publicly reporting on their environmental, social and economic impacts and performance has grown enormously. In essence sustainability reporting is a broad term used to describe a company or an organisation reporting on its environmental social and economic impacts and performance. For the Global Reporting initiative (2011) 'sustainability reporting is the practice of measuring, disclosing, and being accountable to internal and external stakeholders for organizational performance towards the goal of sustainable development.' More specifically the Global Reporting Initiative (2016a) also argued that 'a sustainability report is a report published by a company or organization about the economic, environmental and social impacts caused by its everyday activities.' In reviewing 'the state of play in sustainability reporting within the European Union' van Wensen, Broer, Klein and Knofp (2011) argued that 'sustainability reporting is the provision of environmental, social and governance information within documents such as annual reports and sustainability reports.'

In some ways sustainability reporting has become an 'industry' in itself and a number of private companies and voluntary organisations offer sustainability reporting services and frameworks. The United Nations Environment Programme (2013), for example, identified a number of 'reporting frameworks and protocols, reporting systems, standards and guidelines' and listed five organisations that have 'gained the most widespread uptake' namely the Global Reporting Initiative, the World Resource Institute, the Carbon Disclosure Project, the Climate Disclosure Standards Board and the United Nations Global Compact. However, the United Nations Environment Programme (2013) also reported that the Global Reporting Initiative 'bas become the leading global framework. for sustainability reporting' and cited its comprehensive scope, its commitment to continuous improvement and its consensus approach as being important in contributing to its pre-eminence in the field. Originally founded in 1997 the Global Reporting Initiative reporting framework has progressively evolved from the original G1 Guidelines launched in 2000 to the current G4 Guidelines introduced in 2013.

Within the Current G4 Guidelines materiality and assurance are seen to be of central importance. Materiality is concerned with identifying those environmental, social and economic issues that matter most to a company and its stakeholders. GreenBiz (2014), for example, argued that 'the focus is increasing in the sustainability world on the principle of materiality.' At the same time there is a growing awareness within the business community that external independent assurance of sustainability reports, simply defined, as a process used to provide confidence as to the degree of reliance that can be placed on the information contained in such reports, can enhance their credibility. In making the case for increasing external assurance KPMG (2011), for example, suggested that 'as corporate responsibility reporting begins to play a larger role in the way stakeholders and investors perceive corporate value, companies should increasingly want to demonstrate the quality and reliability of their corporate responsibility data.'

A number of drivers are important in promoting the growth in sustainability reporting. Ernst and Young (2014), for example, argued that 'one of the key drivers bebind the increase in sustainability reporting is that to be meaningful, a sustainability strategy must be based on reliable concrete data. This can only be the case once the mechanisms and systems for reporting the facts are put in place.' Law 360, a US based legal news service, argued that for 'non-governmental, regulators and activists the primary driver for more environmental, social and governance information is mission driven' (Law 360 2015) with stakeholders increasingly pressuring organisations to take responsibility for, and pro-actively manage, the environmental and social impacts of their activities. More generally growing numbers of stakeholders are increasingly demanding greater disclosure from companies on how they are addressing environmental, social and governance issues and other non-financial risks and opportunities.

\section{FOOD AND DRINK WHOLESALING IN EUROPE}

Wholesaling involves the buying of goods directly from producers and manufacturers. usually in large quantities, and their resale, usually in smaller quantities, to retailers and to industrial, commercial, institutional and professional business users. Within Europe wholesaling is a significant sector of the economy generating almost 600 billion Euros annually in added value and employing some 10 million people (Reynolds and Cuthbertson 2014). Indeed, wholesaling has been described as the 'job engine at the centre of Europe's economy' Euro Commerce 2014). Many large wholesalers also increasingly offer a package of integrated business-to-business services (such as account management, sales and after-sale services, technical assistance, category management, logistics, and financial services) to their customers' (Reynolds and Cuthbertson 2014).

In essence the role of food and drinks wholesalers is to buy products in bulk from producers, manufacturers or processors, and provide a supply chain solution for a wide range of businesses particularly small independent retail outlets, convenience stores and hotels, public houses, restaurants, cafes schools and canteens. Within Europe food and drink wholesaling includes a wide range of operators and a number of business models, including private ownership, co-operatives and networks of independent operators. However, two principal systems of wholesale 
distribution can be identified, namely cash and carry businesses and delivered good businesses although some companies employ a combination of both systems. In the former businesses visit large depots to buy and collect goods while in the latter wholesalers offer a delivery service to their retail and catering customers. Generally delivered goods wholesalers have a number of large depots, located on a regional basis, from which the wholesalers deliver using their own haulage fleet. Delivered good wholesaling can be further divided into delivered grocery operations and delivered food service operations.

Within Europe the structure of wholesaling is not as concentrated as that of retailing and while some estimates suggest that there are some 340,000 wholesalers of agricultural and food products (Food and Drink Europe 2015), a number of large companies stand out as market leaders. Metro established its cash and carry concept in Mulheim an der Ruhr, Germany in 1964 and is now a major player in the wholesale trade with some 630 centres in 20 European countries, including Germany (107 centres), France (93), Italy (49), Romania (31), Portugal (10) and Croatia (7) and serves over 20 million customers. The company's centres offer a broad assortment of branded and own label products with up to 20,000 food items including an extensive fresh food range. Coop Schweiz, founded in 1967 and based in Basel Switzerland, has 155 centres in Europe while Carrefour has 148 cash and carry depots in France and a further 12 in other European countries. Within the UK Bestway/Batleys claims to have created the 'cash and carry' concept with the opening of a depot in Huddersfield in 1958 when Batleys traded under the banner 'Come and Get It.' In 2005 Batleys was acquired by Bestway to form the second largest cash and carry wholesale trader in the UK and the company currently trades from 50 depots. These depots are located throughout much of the UK, though they are concentrated in the major population centres of Greater London, the Midlands and North of England and in Central Scotland and many depots also offer a delivered service.

Within the delivered food and drinks wholesale distribution system EDEAKA are major players in Germany, and delivers on a daily basis to over 7,500 retail stores and to hotels and catering establishments from its 38 warehouse depots. The company, originally founded in 1898 and based in Hamburg, bases its wholesale operations around seven regional wholesalers and offers up to 50,000 products including a wide range of fresh fruit and vegetables, fish and seafood products, meats and bread as well as an extensive assortment of grocery products. P\&H has grown steadily through both organic growth and acquisition to become the UK's largest delivered food and drinks wholesaler. The company serves some 90,000 retail outlets from 15 regional depots and operates a fleet of over 1,000 vehicles and it offers some 14,000 ambient, chilled and frozen product lines. Today's Group, founded in 1987, is the largest network of independent delivered wholesalers in the UK. Sligro, originally established in 1935 as a margarine wholesaler, but since the early 1960's the company has grown, largely through acquisition, to become the major wholesaler in the delivered foodservice sector in the Netherlands and serves the hospitality industry and the care sector as well as a number of supermarkets. The company acquired the JAVA foodservice company in Belgium and it also operates some 50 cash and carry depots. Lekkerland supplies some over 100,000 food stores, fast food outlets, convenience stores, petrol station shops and kiosks in Germany, Belgium, Netherlands, Luxembourg, Austria, Switzerland, Spain and Italy from its network of 24 warehouses and its product range includes confectionery, drinks and tobacco goods.

\section{METHOD OF ENQUIRY}

In order to review the sustainability agendas and achievements within the European wholesale industry twelve of Europe's leading wholesalers namely Lekkerland, Metro, Booker, Bestway/Batleys, Carrefour, Costco, Coop Schweiz, Edeka Group, P\&H, Sligro, Today's Group and Norges Gruppen, as identified by the UK's Institute for Grocery Distribution, were selected for study. The selected wholesalers might be seen to reflect contemporary approaches to sustainability within the sector and be keen to publicise their sustainability initiatives to a wide audience. More specifically the authors undertook an Internet search of each of the selected wholesale companies' corporate web sites using the key words 'sustainability' and the name of the selected wholesalers in April 2016 using Google as the search engine. A number of authors have employed content analysis to interrogate websites but in this paper the authors took the decision to tease out the key themes and narratives by a close inspection of the sustainability reports and the information posted on the selected wholesalers' corporate web sites. In taking this decision the authors were minded that little research has been published to date on European food and drink wholesalers' sustainability agendas and thus the need was to discover, rather than to attempt to precisely measure, the companies' approach to sustainability. In addition, the reports and information were structured and signposted and thus a systematic quantitative description did not seem appropriate.

The reports and information are in the public domain and as such the authors took the view that they did not need to contact the selected wholesalers to obtain formal permission prior to conducting their study. The material obtained through this inspection process provided the empirical information for this paper. The specific examples and selected quotations drawn from the leading food and drink wholesalers' corporate websites cited below are used for illustrative rather than comparative purposes and unless specifically cited all quotations are drawn from 
the most recent sustainability reports and information posted on the selected wholesalers' corporate websites. The authors recognise that this approach has its limitations in that there are issues in the extent to which a company's public statements fulsomely, and in detail, reflect strategic corporate thinking and whether or not such pronouncements could be considered little more than carefully constructed public relation exercises. However, the authors believe that their approach offers an accessible window and an appropriate method of enquiry for the purposes of this exploratory study.

\section{FINDINGS}

The findings revealed marked variations in the extent to which the selected wholesalers publicly reported and provided information on their sustainability strategies and achievements. While a number of the selected wholesalers looked to identify specific issues and factors which were seen to underlie their approach to sustainability there was sufficient common ground to allow the identification of the fundamental factors in their sustainability strategies and agendas. Four wholesalers, namely Metro, Bestway/Batleys, Coop Schweiz and Costco, posted dedicated sustainability/corporate social responsibility reports and four companies namely Booker, Carrefour, Sligro and Norges Gruppen reported on sustainability within their annual report. Three wholesalers, Lekkerland, Edeka Group and Today's Group posted some information on their approach to sustainability while the remaining wholesaler, $\mathrm{P} \& \mathrm{H}$ posted no information on sustainability on their corporate website. Two sets of themes, namely the environmental, social and economic issues on which the wholesalers report and provide information on sustainability and the nature of the reporting process, merit attention.

Firstly, the majority of the selected wholesalers which posted sustainability reports or information on sustainability recognised that their operations have a range of environmental, social and, to a lesser extent, economic impacts and many emphasised their strategic commitment to sustainability. Coop Schweiz, for example, reports that it 'pursues a comprehensive approach to sustainability' and that it has 'firmly enshrined sustainability in its articles of association, its corporate profile and its missions.' In a similar vein Metro reported that it 'has firmly embedded the principle of sustainable economic activities in its core business' and that 'we consider environmental and social aspects as part of all entrepreneurial decisions and processes.' Lekkerland reported that the company's 'responsible bandling of resources, partners, employees and products is based on the four pillars of environmental protection, product responsibility, employee orientation and social engagement.' Booker reported that it 'recognises that it has social and environmental responsibilities arising from its operations and is committed to responsible business practices' and more specifically concerning the environment, reported that the company 'recognises its obligation to consider carefully its use of natural resources.'

Many of the selected wholesalers evidenced their strategic commitment to sustainability across a wide range of environmental, social and economic issues and agendas. A number of environmental issues are addressed including climate change and greenhouse gas emissions, energy efficiency and logistics, the harnessing of renewable energy sources, packaging and waste management, sustainability sourcing, site development and building design and biodiversity. Coop Schweiz, for example, stated that 'climate change is one of the biggest challenges facing our society' and under the banner 'Resource Efficiency and Climate Protection' the company reported reducing its absolute carbon dioxide emissions by some $22 \%$ since 2008 and claimed to be on target to reduce emissions by $50 \%$ by 2023 with the remaining $50 \%$ of emissions being offset from that year onwards. Carrefour reported its commitment to reduce carbon dioxide emissions by $40 \%$ compared to 2009 which was seen to demonstrate how the company is striving to limit its impact on climate change.'Between 2011 and 2015 Bestway/Batleys reported on achieving 'a significant absolute reduction in its carbon footprint of around 72\%' despite adding two new depots, extending a third depot and opening a new chilled distribution centre during that period. Booker emphasised that using energy efficiently, minimising our emissions to air and monitoring our energy consumption are key components of our environmental work.'

Some of the selected wholesalers reported on the development of renewable and alternative energy sources. Norges Gruppen, for example, reported running its delivery vehicles on biofuels and that this had led to a reduction in carbon dioxide levels of over 40\% between 2008 and 2014. However, the Norges Gruppen also reported that while it has ambitions to use only renewable fuels at the present time the geographical availability of biofuels and the unsuitability of biofuel motors for long hauls seems likely be a constraint on such ambitions. Norges Gruppen also reported on its plans to erect wind turbines to supply a growing amount of its energy demands and to install solar panels on the roofs of its warehouses. Coop Schweiz reported on its trialling of a solar powered electric truck to make local deliveries in and around Zurich, on its continuing commissioning of biodiesel delivery vehicles and on work on one of its distribution centres which enables the centre to meet $80 \%$ of its heating requirements using groundwater heat pumps.

A number of the wholesalers reported on pursuing programmes designed to reduce energy use and to increase energy efficiency in their logistics operations. Metro, for example, reported 'in order to transport and store goods in a sustainable way..... we select vebicles with low fuel consumption and pollution emissions for our transport fleet, and train our employees in environmentally friendly driving.' Carrefour stressed its commitment to 'improve the performance of vehicle fleets' and 
reported a reduction of over $15 \%$ in its carbon dioxide emissions from its own vehicles and on its commitment to offer incentives to transport contractors with the aim of identifying continuing co-operation on new transportation and information systems. As part of its 'car fleet management' programme Bestway/Batleys emphasised its commitment to 'baving a green car fleet' as evidenced by its purchase of 'bybrid vehicles with low carbon dioxide emissions'.

Waste management is seen to be an important element in many wholesalers' sustainability plans and programmes. Carrefour, for example, emphasised its belief that 'above all preserving natural resources means combating waste' and reported on the company's goal 'to recover $100 \%$ of its waste' which is focused on a circular economic model and local waste management. More specifically Carrefour reported that cardboard, the primary source of waste, is sorted and recycled while the sorting of plastic, metal, glass and bio-waste, is organised utilising local recycling systems. Carrefour also reported on working to identify waste reduction opportunities with its suppliers. Cop Schweiz's approach to waste management is centred upon 'avoiding, reducing and recycling waste wherever possible' and the company reported that during 2013-2014 its recycling rate across its wholesale business was 61\%. In reporting on its approach to 'preventing waste' Booker, for example, claimed it 'continued to work, to prevent waste, redistribute fit for purpose food, increase recycling and divert waste away from landfill.' Each of the company's depots and distribution centres is involved in recycling paper, plastic, cardboard, metal and wood from pallets and during 2014/2015 the company reported increasing the volume of waste recycled and sent to recovery centres by $11 \%$ and reduced waste sent to landfill by $29 \%$.

Some of the selected wholesalers reported on their commitment to sourcing sustainable products. In outlining its approach to 'sustainable products and services' Coop Schweiz, for example, reported that its 'Oecoplan' range of environmentally friendly products, first launched in 1989, must meet stringent requirements based on recognised environmental standards. Coop Schweiz also emphasised that its approach to sustainable sourcing involved scanning its 'entire value chain' and 'addresses those areas where it can make the biggest difference' and reported that in 2014 its focus had been on animal welfare, water management and a reduction in pesticides and that it was 'systematically expanding' its range of Fair Trade products. In addressing animal welfare, for example, Coop Schweiz reported 'championing species appropriate animal husbandry' while in looking to reduce pesticide use the company reported delisting products that were grown using pesticides harmful to bees. Metro reported on its commitment to its 'sustainable product range' and more specifically on its 'eco-friendly fishing practices which preserve stocks.'

In describing its 'biodiversity protection programme' Carrefour recognised that climate change 'will lead to a loss of biodiversity, food resource problems, ocean acidification and a change in the services provided by nature on a daily basis.' In looking to address these challenges Carrefour reported that it had 'decided to take action, in its sphere of influence, to protect biodiversity and ensure that nature continues to produce the resources that mankind needs.' Metro reported on a range of initiatives being pursued within the biodiversity protection programme including the introduction of anti-biotic free animal product ranges, the promotion of agro ecology and organic agriculture, offering its own brand product range free of genetically modified organisms, and the promotion of the sustainable sourcing of palm oil and soya.

Two of the selected wholesalers reported on sustainable construction. Costco, for example, reported on a number of initiatives in its approach to sustainable practices in site development and building design. These included computerised buildings management systems to maximise efficiency, the insulation of building materials, the installation of energy efficient lighting systems and the construction of bio-retention rain gardens. Coop Schweiz reported 'factoring sustainability aspects' into property management and construction and more specifically on promoting sustainability in portfolio management of existing, remodelled and new buildings and on promoting the use of renewable energy.

In addressing the social dimensions of sustainability being addressed by the selected wholesalers a number of themes can be identified including health and wellbeing, links with local communities, charitable donations, as well as diversity, equality of opportunity, health and safety and employee training and staff development within the work environment. Sligro, for example, argued that it focused on 'belping our customers to make healtby choices' and reported on using World Health Organisation guidelines in 'compiling the product range for each customer segment.' More specifically Sligro outlined its commitments to persuade customers to vary their diets, to persuade customers to choose fresh, unprocessed and seasonal products more often and in particular to choose fruit and vegetables, nuts and seeds, wholegrain cereals and pulses and fish. Sligro believe that this approach 'will influence suppliers to adapt their product mix.' Bestway/Batleys, reported on 'supporting initiatives to help improve public health' and on signing up to 'The Public Health Responsibility Deal.' More specifically Bestway/Batleys reported that its public health targets included 'working with our suppliers to improve our offers on healthy products', 'to continue to develop and promote healthy own label products', 'reducing salt and artificial additives in our own label ranges' and 'adopting a clear format for nutritional information on own label packaging.'

The majority of the selected wholesalers reported on their commitment to and links with local communities and on their charitable donations. Lekkerland, for example, emphasised that 'social engagement' was an integral element in its approach to sustainability and reported that 'we therefore take care of the area surrounding our sites and contribute to positive social development.' Bestway/Batleys emphasised its role in 'supporting communities in the UK' which is 
'manifested in the charter of the Bestway Foundation, established in 1987' which undertakes various charitable activities 'geared towards the health and education sectors with preference given to local communities in which we operate.' In addition to its support for local communities Bestway/Batleys also reported on its support for communities overseas and more particularly for its natural disaster rehabilitation and relief efforts. Metro reported on how its employees 'help local people as part of a corporate volunteering programme' and on a 'Community Stars' award which looked to recognise the achievements of independent local businesses in tackling environmental and social issues. Today's Group reported on the establishment of 'Today's Charitable Foundation' and on its funding support for two charities namely 'Bluebell Wood', a children's hospice which offers care and support to children with a shortened life expectancy and their families and to 'Village Water', whose work in rural Zimbabwe supports villages in providing safe water, sanitation and hygiene education.

All the selected wholesalers emphasised their commitment to their employees. Sligro, for example, emphasised that 'we want to offer our employees and their families a challenging, inspiring and safe work environment.' Lekkerland claimed that 'our employees are a crucial success factor for Lekkerland' and that 'we ensure our employees well-being, equality of opportunity and diversity in the company, as well as the possibility of developing oneself within Lekekerland.' In looking to evidence this commitment Sligro reported that its approach includes an employee share ownership and profit sharing scheme, investment in staff development and training, the promotion of diversity and inclusion and the cultivation of long term employment relationships. In addressing its commitment to its employees Booker reported that it was company policy 'to involve colleagues in the business and to ensure that matters of concern to them, including the Group's aims and objectives and financial performance, are communicated regularly in an open manner and where appropriate colleagues views are taken into account.'Booker also stressed that it is 'an inclusive organisation where no one receives less favourable treatment on the grounds of gender, nationality, marital status, colour, race, ethnic origin, sexual orientation or disability.'

Economic issues generally received more limited coverage in the sustainability reports and information posted by the selected wholesalers and focused on employment opportunities, supplier relationships focused on ethical trading and Fair Trade and local and regional sourcing. Booker, for example, reported that it employed over 12,300 people and the corresponding figures for Bestway/Batleys and Lekkerland are 33,600 and 4,900 respectively. Coop Schweiz outlined its commitment to expand its range of Fair Trade products and reported that Fair Trade quality raw materials are procured even when it is not possible to certify the entire product as Fair Trade. 'Some of the selected wholesalers stressed their commitment to local and regional sourcing. Metro, for example, reported that 'when designing and putting together product ranges, our sales lines make a point of including regional products' and argued that 'by procuring products, such as fruit, vegetables and meat from local producers and manufacturers, we not only meet the growing demand for regional products among our customers but also belp our suppliers to build up their operations thereby contributing- together with our customers- to economic development in the respective regions.' Bestway/Batleys reported that the company 'works with over 300 local and regional suppliers across chilled, fresh and frozen foods' and on its commitment 'to developing sustainable business models for local businesses.'

Secondly there were marked variations in the nature of the reporting process. Of the eight selected wholesalers who produced dedicated sustainability reports or reported on sustainability within their annual reports, only four, namely Metro, Carrefour, Coop Schweiz and Sligro, made reference to external reporting guidelines. Sligro, for example, reported that 'the report has been prepared in accordance with the Global Reporting Initiative G4 guidelines' while Norges Gruppen reported that its sustainability report 'follows the criteria set out in version G3 (of the GRI Guidelines) and also defines its own focal points.' Only one of the selected wholesalers, namely Carrefour, looked to introduce the concept of materiality into its sustainability reporting process and here the company described its approach as ' $a$ practicality test' designed to determine the priority environmental and social issues for stakeholders and for the company's business. All the other reports and information made no explicit reference to the role of internal and external stakeholders in identifying the sustainability issues addressed by the wholesalers who would seem to take executive responsibility for this process. Carrefour was also the only one of the selected wholesalers to report on commissioning external assurance and here the external assessors, MAZARS SAS, concluded we did not identify any material misstatements that would lead us to believe that the sustainability information, taken as a whole, has not been fairly presented, in all material aspects, in accordance with the reporting criteria,'

More generally there was little or no uniformity in the character and style of the sustainability reports and information published by the selected wholesalers. A number of the wholesalers include annual data on a range of environmental and social issues but the scope and time scale coverage vary considerably. Coop Schweiz, for example, provided annual statistical returns over a five-year period on over 100 impacts and issues under the umbrella headings 'sustainable products and services', 'resource efficiency and climate protection' and 'employees and society.' The Costco sustainability report included annual data on greenhouse gas emissions over the period 2009-2013, some time series data on the installation of solar panels and some summary statistics on the recycling of organic waste. Bestway/Batleys' sustainability report included summary statistics on reductions in electricity and gas consumption over the period 2011 to 2014, summary data on its investment in lighting upgrades and refrigeration and freezer equipment upgrades and on the increase in the recycling of waste. The sustainability reports and information often 
looked to illustrative general narrative with cameo 'case studies' and with graphs, diagrams and photographic images. While the wholesalers published sustainability reports and information on the Internet there was no evidence that they used it to update sustainability achievements, to harness its interactivity or to allow access to more detailed information, to add value to the reporting process.

\section{DISCUSSION}

While the findings revealed that the majority of Europe's leading food and drink wholesalers publicly recognised the impacts their businesses have on the environment, on society, and to a lesser extent, on the economy, there are marked variations in the character, extent and detail of the reporting process. While a number of the selected wholesalers posted dedicated sustainability reports, others posted only limited information on their approach to sustainability on their corporate websites, though the nature and extent of this information varied considerably, one posted no information on sustainability. The wholesalers' generally idiosyncratic approach to reporting and providing information on sustainability makes it difficult to make any meaningful comparisons between wholesalers or to attempt any evaluation of the contribution wholesalers are making towards the achievement of sustainability targets at national or international levels. This is not a problem per se in that companies have no statutory obligation to report on sustainability but in reviewing the wholesalers' current approach to sustainability a number of issues of issues merit discussion and reflection.

Firstly, while the leading wholesalers are major players in food and drinks distribution within European they currently lag a long way behind their retail counterparts in their approach to sustainability. By way of comparison Europe's leading retailers produce dedicated annual sustainability reports (Jones et. al. 2012). This may reflect the fact that Europe's leading retailers are larger and have more mature management structures and are possibly more attuned to leading edge management thinking and practice than their wholesale counterparts. At the same time it may also reflect the fact that the leading retailers have a high visibility whereas 'many of the largest and most important wholesalers are largely unknown to final consumers' (Armstrong et. al. 2012). As such the leading food and drink wholesalers may currently feel less pressure to publicly demonstrate their accountability, to their customers, to government and to the media than their more visible retail counterparts. That said while the leading European retailers certainly claim a duty of care to their customers and claim to monitor their supply chains to that end, the so called 'horse meat scandal' in 2013 which involved number of European food processing companies highlighted the problems retailers can face in pursuing sustainable sourcing.

Secondly materiality and assurance received limited attention from the selected European wholesalers. There was little reference, for example, to how material issues were identified by the wholesalers or to the role of a range of stakeholders in the identification process. As such the sustainability reports and information posted by the wholesalers might be seen to represent the executive management's approach to sustainability rather than the potentially wider sustainability agendas and concerns of the company's stakeholders. At the same time, the majority of the wholesalers did not report on commissioning independent external assurance and this can be seen to reduce the credibility and the reliability of the wholesalers' sustainability reporting processes. That said Europe's leading wholesalers are large and dynamic organisations and capturing and storing comprehensive information and data throughout the supply chain in a variety of geographical locations and then providing access to allow external assurance is a challenging and a potentially costly venture. Currently the majority of the selected wholesalers choose not to publicly pursue such an exercise.

Thirdly there are issues about the way in which the selected wholesalers implicitly and collectively define sustainability and construct their sustainability agendas. While the majority of the selected wholesalers emphasised their commitment to sustainability they can be seen, individually and collectively, to have constructed a specific definition of the concept. This definition is primarily built around business efficiency and cost savings and is driven more by business imperatives than by any concern with sustainability. While many of the environmental agendas addressed by the selected wholesalers are designed to reduce energy, water consumption and waste emissions, for example, they also serve to reduce costs. In a similar vein the wholesalers' commitments to their employees focusing for example, upon good working conditions, health and safety at work and training all help to promote stability, security, loyalty and efficiency within the workforce.

These business imperatives are most pointedly expressed in the sustainability report posted by Costco. In addressing climate change, for example, Costco reported factors associated with climate change could adversely affect our business' and that increased government regulation 'to limit carbon dioxide and other greenhouse gas emissions may result in increased compliance costs and legislation or regulation affecting energy inputs that could materially affect our profitability.' Costco further reported that 'climate change could affect our ability to procure needed commodities at costs and in quantities we currently experience.' In addressing its responsibilities within the workplace Bestway/Batleys expressed its belief that 'our business performance depends upon the commitment, determination and creativity of our people' and 'for this reason we encourage the continuous development of employees through comprehensive training programmes.' 
The selected wholesalers might thus be seen to have constructed sustainability agendas, which are driven primarily, though not necessarily exclusively, by their own commercial interests. The accent being on efficiency gains across a wide range of economic, social and environmental issues rather than on maintaining the viability of natural ecosystems and reducing demands on finite natural resources. As such the wholesalers approach to sustainability might be interpreted as being focussed upon business continuity rather than that originally defined by the World Commission on Environment and Development as cited earlier in this paper. In some ways the food and drink wholesalers approach to sustainability can be seen to be consistent with the view that good ethics can have a positive impact on the performance of firms (e. g. Canon 1996: Joyner and Payne 2002) and with the more recently developed concept of creating shared value, 'defined as policies and practices that enhance the competitiveness of $a$ company while simultaneously addressing the economic and social conditions in the communities in which it operates' (Porter and Kramer 2011). More critically Aras and Crowther (2009) argued that corporate sustainability reporting has the effect of obscuring "the effect of corporate activity upon the external environment and the consequent implications for the future" and that 'one of the effects of persuading that corporate activity is sustainable is that the cost of capital for the firm is reduced as investors are misled into thinking that the level of risk involved in their investment is lower than it actually is.' In a similar vein Banerjee (2008) has argued that 'despite their emancipatory rhetoric, discourses of corporate citizenship, social responsibility and sustainability are defined by narrow business interests and serve to curtail the interests of external stakeholders.'

Thirdly and looking to the future it is important to recognize that food and drinks distribution is a dynamic sector of the European economy and that developments in information and communication technologies, particularly the internet, are having a major effect on traditional business models. In this context the impact of disintermediation, or the elimination of elements within supply chains, has attracted some attention in the literature and Chen (2003), for example, has outlined the potential effects on interactive technologies on the survival and failure of business models. More specifically Morschett (2012) suggested that wholesalers can 'emphasize different functions in its offer and that this influences the risk of being eliminated from distribution channels' and he suggested that emphasisng the logistics function works positively for the wholesaler while a focus on the marketing function increases the likelihood of disintermediation. Research in the US by Rovit et. al. (2002) suggested that wholesalers who look to grow local market share, to select their service offer carefully to increase margins, and to reduce their operating costs can grow in the face of potential disintermediation. How disintermediation might affect a wholesaler's approach to sustainability may be mixed. On the one hand a focus on reducing operating costs, for example, can promote the search for continuing efficiencies in energy and water use, but it may also reduce overall commitment to, and investment in, wider sustainability goals.

Fourthly companies currently have no statutory obligation to report on their sustainability performance. However, following a recent European Union Directive (Global Reporting Initiative 2016b), companies with over 500 employees will be required to report on environmental and social matters once member states transpose the Directive into national laws. While the expectation is that the first such reports will be published in 2018 covering the financial year 2017-2018 it remains to be seen how rapidly member states will introduce the necessary legislation, if countries outside the EU will adopt a similar approach and if, and how, this will encourage food and drink wholesalers to pursue more comprehensive sustainability strategies. More generally following the ratification of the Sustainable Development Goals (SDGs) at a United Nations General Assembly in 2015 (United Nations 2015) the call was for all governments to develop national strategies to implement these ambitious and wide ranging targets. That said PricewaterhouseCoopers (2015) argued that when governments sign up to the SDGs they will look to society and business in particular for help to achieve them' and that 'business will need to assess its impact on the SDGs and review it strategy accordingly.' 'The United Nations Global Compact and KPMG (2016) have published guidance on how companies within the food, beverage and consumer goods industry might respond to the challenge of the SDGs and within the UK, for example, the Institute for Grocery Distribution, the representative body for the Food and drinks industry (2016) the Federation for Wholesale Distributors (2011) have both been developing guidelines on sustainability. However here again it remains to be seen how effectively and how rapidly these guidelines will promote the pursuit of more comprehensive sustainability strategies amongst food and drinks wholesalers.

Finally, there are arguably more fundamental issues concerning the underlying tensions between sustainability and economic growth. With an eye to the future the sustainability reports and information posted by a number of the selected wholesalers are couched within the idiom of continuing growth and business expansion. In his introduction to Lekkerland's 2014 Annual Report, for example, the Chief Executive Officer reported in the future we will be intensely pursuing sustainable growth' (Lekkerland 2014). In some ways this reflects the distribution sector's general position as epitomized by Sir Terry Leahy, the then Chief Executive Officer of 'Tesco, in his 'Foresight' contribution at the start of The Global Coca Cola Retailing Research Council Forum (2009) report. He argued that, at that time, his company was 'seeking to create a movement which shows that it is possible to consume, to be green and to grow'. Such an approach is rooted in the general belief that continuing economic growth will inevitably be accompanied by the more efficient use of resources. This trend which is seen as either relative or absolute 
decoupling (relative decoupling refers to using fewer resources per unit of economic growth while absolute decoupling refers to a total reduction in the use of resources) underpins many conventional definitions of sustainability and the vast majority of current corporate sustainability strategies and programmes. However Wiedmann et. al. (2015) argued that 'achievements in decoupling in advanced economies are smaller than reported or even nonexistent' and this, in turn, may be seen to ultimately undermine the potential to achieve sustainable growth. More generally the radical zero growth approach to sustainability continues to be dismissed within the business community.

The concept of sustainable consumption, which Cohen (2005) has described as the most obdurate challenge for the sustainable development agenda' receives limited attention in the sustainability reports and information posted by the leading wholesalers. In arguing that 'Europe must take the lead in exploring a new model of consumption which does not compromise the needs of others or of future generations, nor damage the environment' in for The European Environment Agency (2012) branded 'unsustainable consumption' as 'the mother of all environmental issues.'That said within Europe there is little evidence of genuine consumer appetite for sustainable consumption and here the European Commission's (2012) recognition that 'sustainable consumption is seen by some as a reversal of progress towards greater quality of life' in that 'it would involve a sacrifice of our current, tangible needs and desires in the name of an uncertain future' resonates. This view is supported by Reisch et.al. (2008) who argued that although moving towards sustainable consumption is a major policy agenda, growth of income and material throughput by means of industrialization and mass consumerism remains the basic aim of western democracy.' More critically Castro (2004) has questioned the very possibility of sustainable development under capitalism and argued that economic growth relies upon the continuing and inevitable exploitation of both natural and social capital.

\section{CONCLUSION}

The majority of Europe's leading food and drink wholesalers, either publicly reported on, or provided information on, their commitments to sustainability. A minority either explicitly or implicitly argued that by integrating sustainability into their businesses, they are better placed to provide long term growth and financial security for all stakeholders and to enhance their market position and reputation. However, the authors argue that the leading food and drink wholesalers' definitions of, and commitments to, sustainability can be interpreted as being driven as much by business imperatives as by any fundamental commitments to sustainability. Thus the accent currently appears to be on making efficiency gains across a wide range of economic, social and environmental issues rather than on maintaining the viability and integrity of natural ecosystems and on reducing demands on finite natural resources. As such Europe's leading wholesalers are, at best, pursuing a 'weak' rather than a 'strong' model of sustainability. More critically the authors suggest that the leading food and drink wholesalers' commitments to sustainability are couched within existing business models centred on continuing growth and consumption and that current policies might be viewed as little more than genuflections to sustainability. This echoes Roper's (2012) belief that weak sustainability represents 'a compromise that essentially requires very little change from dominant economic driven practices but effectively works to defuse opposition, increase legitimacy and allow business as usual'. At the present time Europe's leading food and drink wholesalers are thus effectively and conveniently ignoring the idea that present patterns of consumption may simply be unsustainable in the long term.

\section{REFERENCES}

Aras, G. and Crowther, D. (2008). Governance and Sustainability: An investigation into the relationship between corporate governance and corporate sustainability. Management Decision, 46(3), pp. 433-448.

Aras, G. and Crowther, D. (2009). Corporate Sustainability Reporting: A Study in Disingenuity? Journal of Business Ethics, 87(1), pp. 279-288.

Azapagic, A. (2003). Systems Approach to Corporate Sustainability. Transactions of the Institute of Chemical Engineers, 81(5), pp.303-316.

Armstrong, G., Kotler, P., Harker, M. and Brennan, R. (2012). Marketing: An Introduction. Pearson, Harlow.

Banerjee, S.B. (2008). Corporate Social Responsibility: The Good, the Bad and the Ugly. Critical Sociology, 34(1), pp. 51-79.

Cannon, T. (1996) A Textbook on Business Ethics, Governance and the Environment. Pitman, London.

Castro, C. (2004). Sustainable Development: Mainstream and Critical Perspectives, Organisation and Environment, $17(2), 195-225$.

Chen, S. (2003). The real value of e-business models. Business Horizons, 46(6), pp. 27-33.

Cohen, M.J. (2005). Sustainable consumption in a national context; an introduction to the symposium, [online] Available at: http://ejournal.nbii.org/archives/vol1iss1/0410-008.cohen.html [Accessed 16 November 2015]. 
CSR QUEST (2014). Corporate Sustainability Definition, [online] Available at: http://www.csrquest.net/default.aspx?articleID=13113 [Accessed 17 January 2016].

Diesendorf, M. (2000). Sustainability and Sustainable Development. In: D. Dunphy, J. Beneveniste, A. Griffiths and P. Sutton, ed., Sustainability: The corporate challenge of the 21st century, Sydney: Allen and Unwin.

Durieu, X. (2003). How Europe's retail sector helps to promote sustainable production, Industry and Environment, 26(1), pp. 7-9.

Dyllick, T. and Hockerts, K. (2002). Beyond the Business Case for Corporate Sustainability, Business Strategy and the Environment, 11(2), pp. 130-141.

Ernst and Young (2014). Sustainability Reporting: The time is now, [online] Available at: http://www.ey.com/Publication/vwLUAssets/EY_Sustainability_reporting_the time is now/\$FILE/EY-Sustainability-reporting-the-time-is-now.pdf [Accessed 7 April 2016].

EuroCommerce (2014). Wholesale: Job Engine at the Centre of Europe's Economy, [online] Available at: http://www.eurocommerce.eu/media/78569/eurocommerce brochure wholesales v2 150223.pdf [Accessed 4 April 2016].

European Commission (2012). Policies to Encourage Sustainable Consumption, [online] Available at: http://ec.europa.eu/environment/archives/eussd/pdf/report 22082012.pdf [Accessed 3 February 2016].

European Environment Agency (2012). Unsustainable consumption - the mother of all environmental issues, [online] Available at: http://www.eea.europa.eu/highlights/unsustainable-consumption-2013-the-mother [Accessed 3 February 2016].

Federation of Wholesale Distributors (2011). A Wholesale Commitment to Sustainability, [online] Available at: http://imaemfwd.blob.core.windows.net/website/resources/58.pdf [Accessed 6 June 2016].

Food and Drink Europe (2015). European Food and Drink Industry 2014-2015, [online] Available at: http://www.fooddrinkeurope.eu/uploads/publications documents/Data and Trends 2014-20151.pdf [Accessed 4 April 2016]

Global Association of Corporate Sustainability Officers (2011). Defining and developing the corporate sustainability professional, [online] Available at: http://www.gacso.org/Resources/Documents/defining\%20the $\% 20$ corporate $\% 20$ sustainability $\% 20$ professio nal.pdf [Accessed 23 April 2014].

Global Reporting Initiative (2011). Sustainability Reporting Guidelines, [online] Available at: https://www.globalreporting.org/resourcelibrary/G3.1-Guidelines-Incl-Technical-Protocol.pdf [Accessed 12 April 2016].

Global Reporting Initiative (2016a). Benefits of Reporting, [online] Available at: https://www.globalreporting.org/information/sustainability-reporting/Pages/reporting-benefits.aspx [Accessed 12 April 2016].

Global Reporting Initiative (2016b). Sustainability Reporting in the European Union, [online] Available at: https://www.globalreporting.org/information/policy/Pages/EUpolicy.aspx [Accessed 6 July 2016].

GreenBiz (2014). 4 top sustainability reporting trends for 2014, [online] Available at: http://www.greenbiz.com/blog/2014/02/20/top-sustainability-reporting-trends-2014 [Accessed 7 January 2015].

Institute of Grocery Distribution (2016). Environmental Sustainability Matrix: Understanding Sustainability Issues Across The Supply Chain, [online] Available at: http://www.igd.com/Research/Sustainability/EnvironmentalSustainability-Matrix-Understand-sustainability-issues-across-the-supply-chain/ [Accessed 6 June 2016].

Jones, P., Comfort, D. and Hillier, D. (2012). Sustainability in the European Shop Window. European Retail Research, 26(1), pp. 1-19.

Joyner, B.E. and Payne, D. (2002). Evolution and Implementation: A Study of Values, Business Ethics and Corporate Social Responsibility. Journal of Business Ethics, 41(4), pp. 297-311.

KPMG (2011). Sustainability reporting what you need to know, [online] Available at: https://www.kpmg.com/US/en/IssuesAndInsights/ArticlesPublications/Documents/iarcs-sustainabilityreporting-what-you-should-know.pdf [Accessed 7 April 2016].

Kamara, M., Coff, C. and Wynne, B. (2006). GMO's and Sustainability, [online] Available at: http://www.cesagen.lancs.ac.uk/resources/docs/GMOs_and_Sustainability_August_2006.pdf [Accessed 15 February 2014].

Law 360 (2015). Emerging Trends in Corporate Sustainability Reporting, [online] Available at: http://www.law360.com/articles/624183/emerging-trends-in-corporate-sustainability-reporting [Accessed 12 April 2016].

Lekkerland (2014). Annual report, [online] Available at: http://www.lekkerland.com/le/media/content/downloads/company 3/gb 2014/141006 Lekkerland GB2

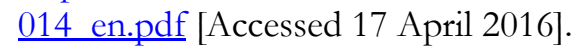


Morschett, D. (2012). Disintermediation in Distribution Channels- A Transaction Cost-based Analysis of Wholesalers, European Retail Research, 26(2), pp. 93-112.

Polentz, M.C. (2011). The Real World Application of Corporate Sustainability, [online] Available at: http://www.environmentalleader.com/2011/07/17/the-real-world-application-of-corporate-sustainability/ [Accessed 17 April 2014].

Porter. M.E. and Kramer, M.R. (2011). Strategy and society: the link between competitive advantage and corporate social responsibility, Harvard Business Review, 87, pp. 78-92.

PricewaterhouseCoopers (2015). Making It Your Business; Engaging with the Sustainable Development Goals, [online] Available at: https://www.pwc.com/gx/en/sustainability/SDG/SDG\%20Research FINAL.pdf [Accessed 30 June 2016].

Reisch, L., Spash, C.L. and Bietz, S. (2008). Sustainable Consumption and Mass Communication: A German Experiment, [online] Available at: http://www.csiro.au/files/files/pm9m.pdf [Accessed 23 March 2014].

Reynolds, J. and Cuthbertson, R. (2014). Retail and Wholesale: Key Sectors For the European Economy, [online] Available at: http://www.eurocommerce.eu/resource-centre.aspx\#Publication/7459 [Accessed 2 April 2016].

Roper, J. (2012). Environmental risk, sustainability discourses and public relations. Public Relations Inquiry, 1(1), pp. 69-87.

Rovit, S., Sweder, K. and Buchanan, J. (2002). How top wholesalers success: secrets of a brutal business, Strategy and Leadership, 30(2), pp. 32-37.

The Global Coca Cola Retailing Research Council Forum (2009). Sustainability in Retailing, [online] Available at: http://www.coke.net/app/public/ccrrcgrp/CCRRC GLOBAL.pdf [Accessed 27 April 2014].

United Nations (2015). Transforming Our World: The 2030 Agenda for Sustainable Development, [online] Available at: https://sustainabledevelopment.un.org/content/documents/21252030\%20Agenda $\% 20$ for $\% 20$ Sustainable $\%$ 20Development $\% 20$ web.pdf [Accessed 28 April 2016].

United Nations Environment Programme (2013). Frequently Asked Questions on Corporate Sustainability Reporting, [online] Available at: https://www.globalreporting.org/resourcelibrary/GoF47Para47-FAQs.pdf [Accessed 6 April 2016].

United Nations Global Compact and KPMG (2016). SDG Industry Matrix; Food, Beverages and Consumer Goods, [online] Available at: https://www.unglobalcompact.org/library/3961 [Accessed 28 May 2016].

van Wensen, K., Broer, W., Klein, J. and Knofp. J. (2011). The State of Play in Sustainability Reporting in the European Union, [online] Available at: http://ec.europa.eu/social/main.jsp?langId=en\&catId=89\&newsId=1013 [Accessed 4 April 2016].

Wiedmann, T.O., Manfred, S., Lenzen, M., Moran. D., Suh, S., West, W. and Kanemoto, K. (2015). The Material Footprint of Nations. Proceedings of the National Academy of Sciences, 112(20), pp. 6271-6276.

World Commission on Environment and Development (1987). Our Common Future, [online] Available at: http://www.un-documents.net/ocf-02.htm [Accessed 30 July 2014]. 